\title{
Spectrophotometric Determination of Dopamine in Bulk and Dosage Forms Using 2,4-Dinitrophenylhydrazine
}

\section{2,4-Dintrofenilhidrazin Kullanılarak Dopaminin Yığın ve Dozaj Formlarının Spektrofotometrik Tayini}

\author{
(D) Mai Abed Alrahman RAMADAN*, (D) Ihab ALMASRI, (D) Ghada KHAYAL \\ Al-Azhar University-Gaza Faculty of Pharmacy, Department of Pharmaceutical Chemistry and Pharmacognosy, Gaza, Palestine
}

\begin{abstract}
Objectives: Dopamine (DA) hydrochloride is a sympathomimetic agent used therapeutically for the correction of hemodynamic disorders associated with shock episodes. Although several analytical methods have been described, a spectroscopic assay of DA after chemical derivatization with 2,4-dinitrophenylhydrazine (DNP) is still unexamined. Therefore, the optimization of the reaction parameters and validation of developed method were required.

Materials and Methods: The method is based on coupling of DA as a phenolic compound with a diazonium salt to produce an intensely colored azo derivative. DNP was oxidized with potassium periodate to produce a diazonium salt that coupled with DA in basic media. The experimental parameters were then optimized. The developed method was validated according to International Conference on Harmonisation Guidelines and was applied to dosage forms. The results were compared with the data of a reference method.

Results: The method was linear in a concentration range between 5 and $50 \mu \mathrm{g} / \mathrm{mL}$. The regression line equation was $Y=0.042 \pm 0.0003 X+0.0672 \pm 0.0015$ with a regression coefficient of $0.9944(n=5)$. The limit of detection and limit of quantification were $0.32 \mathrm{and} 0.97 \mu \mathrm{g} / \mathrm{mL}$, respectively. The precision was satisfactory; the percentage relative standard deviation did not exceed $2 \%$. The average values of the recovery study were in the range $98.90-$ $100.40 \pm 0.31-1.21 \%$. The developed method was applied successfully for the determination of DA in injection and infusion fluid.

Conclusion: The method is accurate, sensitive, and practical for DA analysis in quality control laboratories.
\end{abstract}

Key words: Dopamine hydrochloride, 2,4-dinitrophenylhydrazine, spectrophotometric, validation

öz

Amaç: Dopamin (DA) hidroklorür, şok epizodlarında hemodinamik bozuklukların düzeltilmesinde terapötik olarak kullanılan bir sempatomimetik ajandır. Çok sayıda analitik yöntem tanımlanmasına rağmen, 2,4-dinitrofenilhidrazin (DNP) ile kimyasal türevlendirme sonrası DA'nın spektroskopik analizi henüz incelenmemiştir. Bu nedenle, reaksiyon parametrelerinin optimizasyonu ve geliștirilen yöntemin geçerliliği gereklidir.

Gereç ve Yöntemler: Yöntem, DA'nın bir fenolik bileşik olarak diazonyum tuzu ile birleştirilmeyle yoğun renkli bir azo türevinin oluşturulmasına dayanır. DNP potasyum periyodat ile okside edilmiş, bazik ortamda DA ile birleștirilerek diazonyum tuzu olușturulmuştur. Sonrasında reaksiyon parametreleri optimize edilmiştir. Geliştirilen yöntem Uluslararası Uyum Konferansı Kılavuzları'na göre valide edilmiş ve dozaj formlarına uygulanmıştır. Sonuçlar bir referans yönteminin verileriyle karşılaştırılmıştır.

Bulgular: Yöntemin doğrusallığı 5 ila $50 \mu \mathrm{g} / \mathrm{mL}$ arasındadır. Regresyon çizgisi denklemi $\mathrm{Y}=0,042 \pm 0,0003 X+0,0672 \pm 0,0015$, regresyon katsayısı ise $0,9944(n=5)$ olarak saptanmıştır. Deteksiyon limiti ve kantifkasyon limiti sırasıyla 0,32 ve 0,97 $\mu \mathrm{g} / \mathrm{mL}$ 'dir. Hassasiyet düzeyi yeterli seviyede

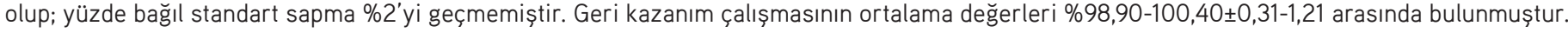
Geliştirilen yöntem enjeksiyon ve infüzyon sıvısında DA tayini için başarıyla uygulanmıştır.

Sonuç: Yöntem, DA analizi için doğru ve hassastır ve kalite kontrol laboratuvarlarında kullanımının pratik olduğu söylenebilir.

Anahtar kelimeler: Dopamin hidroklorür, 2,4-dinitrofenilhidrazin, spektrofotometrik, validasyon

*Correspondence: E-mail: m.ramadan@alazhar.edu.ps, Phone: +972-059-9906430 ORCID-ID: orcid.org/0000-0001-8032-5777

Received: 23.09.2019, Accepted: 21.11.2019

Turk J Pharm Sci, Published by Galenos Publishing House. 


\section{INTRODUCTION}

The chemical name for dopamine (DA) hydrochloride is 1,2-benzenediol,4-(2-amonoethyl) hydrochloride. DA is an endogenous catecholamine that is a sympathomimetic agent with prominent dopaminergic and $\beta_{1}$-adrenergic effects at low to moderate doses and $\alpha$-adrenergic effects at high doses. It is used for the correction of hemodynamic disorders associated with shock episodes. ${ }^{12}$

A literature survey of DA revealed several methods for its determination in injection. Spectrophotometric methods using bromanil, 2,6-dichloroquinone-4-chloroimide, 3-amiopyridine, chloramine $\mathrm{T}$, and various oxidative coupling based methods were published. ${ }^{3-10}$ In addition, different high performance liquid chromatography (HPLC), ${ }^{11-15}$ flow injection, ${ }^{16,17}$ fluorimetric, ${ }^{18}$ capillary electrophoresis, ${ }^{19}$ chemiluminescence, ${ }^{20}$ and electrochemical ${ }^{21-26}$ methods were reported.

Spectrophotometry is considered the most practical analytical procedure in quality control laboratories, since it does not need costly instrumentation or toxic solvents like chromatography does. 2,4-dinitrophenylhydrazine (DNP) is a derivatizing agent used in the analysis of many drugs. ${ }^{27-31}$ Chemical derivatization prior to spectroscopic analysis enhances both sensitivity and selectivity. ${ }^{32}$

The current study was performed, in continuation of our interest in the development and validation of simple, sensitive, and rapid spectrophotometric methods for the analysis of drugs, 33,34 to determine DA depending on a derivatization reaction with DNP in pharmaceuticals.

\section{MATERIALS AND METHODS}

\section{Instruments}

The spectrophotometers used were a Shimadzu ultraviolet (UV)-1601 with UV-Pro software (Shimadzu, Japan) and a Lambda 25 with V5 ES software (PerkinElmer, USA) and 1-cm quartz cells (Innovative Lab Supply, USA).

\section{Materials}

All chemicals used were of analytical grade. DA hydrochloride standard was purchased from Merck (Germany). DA dosage forms were ampoules for infusion (200 mg/5 mL) and DA hydrochloride with $5 \%$ dextrose infusion fluid $(800 \mu \mathrm{g} / \mathrm{mL}$ DA) obtained from a local hospital pharmacy (Gaza, Palestine).

\section{Preparation of reagents}

DNP, $0.005 \mathrm{M}$ reagent: $0.10 \mathrm{~g}$ of DNP was accurately weighed and transferred into a $100 \mathrm{~mL}$ volumetric flask, dissolved in $2.5 \mathrm{~mL}$ of concentrated sulfuric acid, and completed up to the volume with distilled water. The solution was freshly prepared and protected from light during use because it is light sensitive.

Potassium periodate [(PPI), $0.0065 \mathrm{M}$ ] reagent: $0.15 \mathrm{~g}$ of PPI was accurately weighed and transferred into a $100 \mathrm{~mL}$ volumetric flask, dissolved, and completed up to the volume with distilled water.

Sodium hydroxide $[(\mathrm{NaOH}), 10 \mathrm{M}]: 40.00 \mathrm{~g}$ of $\mathrm{NaOH}$ was accurately weighed and transferred into a volumetric flask, dissolved, and completed up to the volume of $100 \mathrm{~mL}$ with distilled water.

\section{Standard stock solution}

It was prepared by dissolving $0.02 \mathrm{~g}$ of DA hydrochloride standard in $100 \mathrm{~mL}$ of distilled water $(200 \mu \mathrm{g} / \mathrm{mL})$. Working solutions were prepared by diluting the stock solution. The stock solution was freshly prepared during use.

\section{General procedure}

An aliquot of standard stock solution was transferred into a 10 $\mathrm{mL}$ volumetric flask followed by $1.0 \mathrm{~mL}$ of DNP, $1.0 \mathrm{~mL}$ of PPI, and $0.5 \mathrm{~mL}$ of $\mathrm{NaOH}$ reagents. The mixture was mixed well and diluted to $10 \mathrm{~mL}$ with distilled water at room temperature. The absorbance was measured at absorption maximum $\left(\lambda_{\max }\right) 560$ $\mathrm{nm}$ against a blank.

\section{Determination of stoichiometric ratio (Job's method)}

Job's method of continuous variation was employed. ${ }^{35}$ Equimolar $\left(3 \times 10^{-3} \mathrm{M}\right)$ aqueous solutions of DA and DNP were prepared. Series of $1.0 \mathrm{~mL}$ portions of DA and DNP were made up comprising different complementary volumes (0.0:1.0, 0.1:0.9, 0.2:0.8, 0.3:0.7, 0.4:0.6, 0.5:0.5, 0.6:0.4, 0.7:0.3, 0.8:0.2, 0.9:0.1, 1.0:0.0) in $10 \mathrm{~mL}$ volumetric flasks. The process followed the general procedure. Absorbance was plotted against DNP molar fraction.

\section{Optimization of reaction conditions}

Different reaction parameters were studied. They included concentration and volume of DNP, PPI, and $\mathrm{NaOH}$; temperature; reaction time; order of addition; and stability of the developed chromogen. The study was carried out by altering one factor and keeping the others constant.

\section{Method validation}

Validation parameters were determined according to International Conference on Harmonisation (ICH) guidelines. ${ }^{36}$

\section{Assay of pharmaceutical formulations}

The content of three ampoules for DA was mixed and an accurately measured volume equivalent to $0.020 \mathrm{~g}$ of DA was transferred to a $100 \mathrm{~mL}$ volumetric flask. Distilled water was added to bring the volume up to $100 \mathrm{~mL}$.

For DA and $5 \%$ dextrose infusion fluid, the content of three bottles was mixed and an accurately volume equivalent to 0.02 $\mathrm{g}$ was transferred into a $100 \mathrm{~mL}$ volumetric flask and diluted with water. It was further diluted to get a concentration of working solutions. Analysis was performed as described in the general procedure.

\section{Statistical analysis}

Data analysis was performed using SPSS version 17 to calculate the regression equation, coefficient factor, standard deviation, relative standard deviation (RSD), t-test, and $p$ value.

\section{RESULTS}

In order to enhance sensitivity a derivatization reaction of DA using DNP was performed. A red shifted DA derivative was 
produced, which showed an $\lambda_{\text {max }}$ at $560 \mathrm{~nm}$ (Figure 1). The reaction parameters were optimized (Table 1 ). The reaction was completed immediately at room temperature. Heating was not advantageous due to intermediate (diazonium) instability. To DA solution was added DNP followed by $\mathrm{PPI}$ and $\mathrm{NaOH}$ (Table 2). DNP was oxidized by PPI to form a diazonium ion and the $\mathrm{pH}$ was still acidic. Once diazonium formed it attacked the electron-rich phenolic DA. The last step required basic media. Addition of PPI to DA (Table 2) was unsuitable since it can lead to oxidation of the catechol moiety of DA. When $\mathrm{NaOH}$ was added to DA the absorption was decreased. This can be explained by phenoxide formation and inappropriate media for diazonium salt formation. ${ }^{37}$ - The best result was achieved when $1 \mathrm{~mL}$ of both DNP and PPI reagents and 0.5 $\mathrm{mL}$ of $\mathrm{NaOH}$ were added to DA in the mentioned order. After dilution the DA derivative was stable for at least 15 min (Figure 2), which allowed processing of samples and their comfortable measurement. The stoichiometric ratio of the DA-derivatization reaction was studied by Job's method. The molar ratio was 1:1

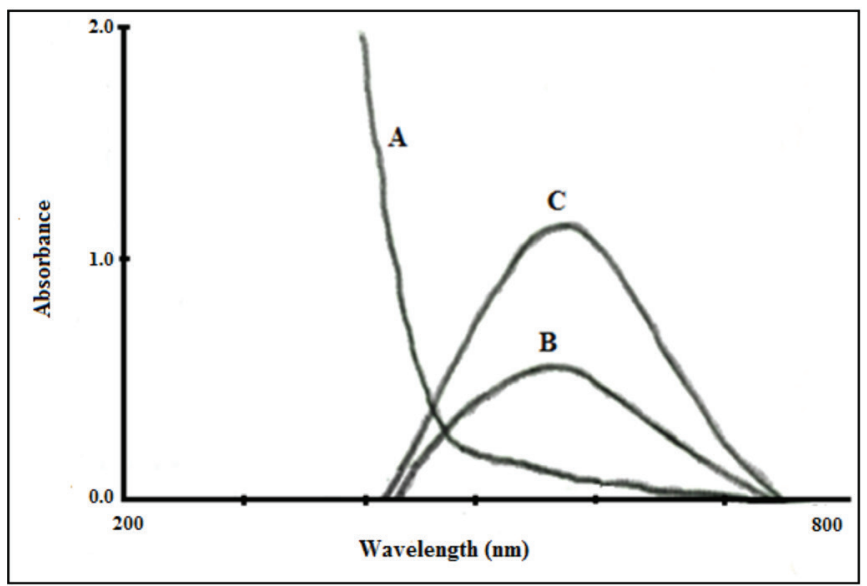

Figure 1. Absorption spectra. A) Blank spectrum against water; B, C) derivatization products against blank (DA: 10 and $30 \mu \mathrm{g} / \mathrm{mL}$ ), respectively

DA: Dopamine

Table 1. Summary of optimum conditions for DA-derivatization reaction

\begin{tabular}{lll} 
Variable & Studied rangea & Optimum \\
\hline DNP concentration & $0.0015-0.010 \mathrm{M}$ & $0.005 \mathrm{M}$ \\
\hline Volume of DNP $(0.005 \mathrm{M})$ & $0.5-2.5 \mathrm{~mL}$ & $1.0 \mathrm{~mL}$ \\
\hline PPI concentration & $0.0017-0.011 \mathrm{M}$ & $0.0065 \mathrm{M}$ \\
\hline Volume of PPI $(0.0065 \mathrm{M})$ & $0.5-2.5 \mathrm{~mL}$ & $1.0 \mathrm{~mL}$ \\
\hline $\mathrm{NaOH}$ concentration & $5-10 \mathrm{M}$ & $10 \mathrm{M}$ \\
\hline Volume of $\mathrm{NaOH}(10 \mathrm{M})$ & $0.2-2.0 \mathrm{~mL}$ & $0.5 \mathrm{~mL}$ \\
\hline Temperature & $25-60^{\circ} \mathrm{C}$ & $25^{\circ} \mathrm{C}$ \\
\hline Time & $0-60 \mathrm{~min}$ & $0 \mathrm{~min}$ \\
\hline Order of addition & Different & $\mathrm{b}$
\end{tabular}

a: DA $10 \mu \mathrm{g} / \mathrm{mL}$, DNP, PPI, and $\mathrm{NaOH}$ were mixed according to tested factor, $\mathrm{H}_{2} \mathrm{O}$ diluting solvent, absorbance at $560 \mathrm{~nm}$, b: For best order of addition see Table 2 DA: Dopamine, DNP: 2,4-dinitrophenylhydrazine, PPI: Potassium periodate, $\mathrm{NaOH}$ : Sodium hydroxide for DA and DNP (Figure 3). Accordingly, a proposed mechanism of the reaction is illustrated in Figure 4 depending on the result for the molar ratio and the mechanism of azo formation.

\section{Method validation}

\section{Linearity and sensitivity}

For evaluation of linearity DA was determined at optimized conditions for five concentrations. The calibration curve was $Y=0.042 \pm 0.0003 X+0.0672 \pm 0.0015(r=0.9944, n=5)$, where $Y$ is Table 2. Effect of order of addition on DA analysis

\begin{tabular}{llllll} 
Sample & First & Second & Third & Fourth & $\begin{array}{c}\text { Absorbance } \\
(\text { Mean } \pm \text { SD) }\end{array}$ \\
\hline 1 & DA & DNP & PPI & $\mathrm{NaOH}$ & $0.473 \pm 0.005$ \\
\hline 2 & DA & PPI & DNP & $\mathrm{NaOH}$ & $0.451 \pm 0.013$ \\
\hline 3 & DA & $\mathrm{NaOH}$ & $\mathrm{PPI}$ & $\mathrm{DNP}$ & $0.442 \pm 0.001$ \\
\hline 5 & $\mathrm{DA}$ & $\mathrm{NaOH}$ & $\mathrm{DNP}$ & $\mathrm{PPI}$ & $0.447 \pm 0.001$ \\
\hline 6 & $\mathrm{DNP}$ & $\mathrm{PPI}$ & $\mathrm{DA}$ & $\mathrm{NaOH}$ & $0.450 \pm 0.010$ \\
\hline
\end{tabular}

a: Values are means of three determinations, DA $10 \mu \mathrm{g} / \mathrm{mL}$, DNP $(0.005 \mathrm{M}, 1.0$ $\mathrm{mL}), \mathrm{PPI}(0.0065 \mathrm{M}, 1.0 \mathrm{~mL}), \mathrm{NaOH}(10 \mathrm{M}, 0.5 \mathrm{~mL}), \mathrm{H}_{2} \mathrm{O}$ diluting solvent, at room temperature, absorbance at $560 \mathrm{~nm}$

DA: Dopamine, DNP: 2,4-dinitrophenylhydrazine, PPI: Potassium periodate, $\mathrm{NaOH}$ : Sodium hydroxide, SD: Standard deviation

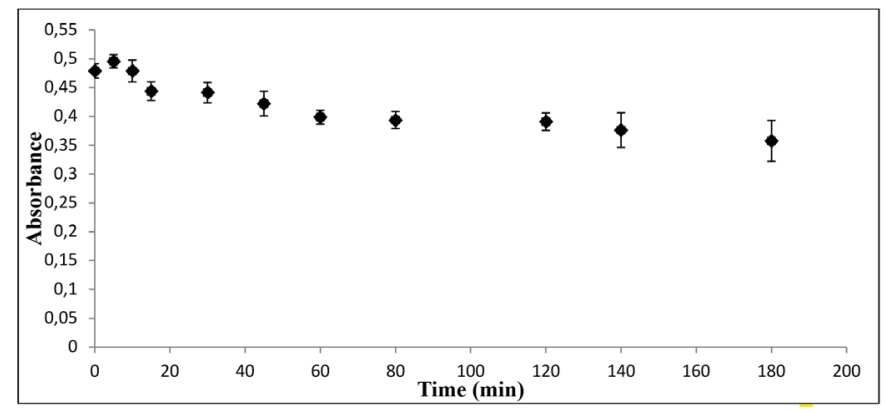

Figure 2. Stability of chromogen resulting from the reaction of DA with DNP. DA $(10 \mu \mathrm{g} / \mathrm{mL})$, absorbance is average of three determinations. Error bars represent standard deviation

DA: Dopamine, DNP: 2,4-dinitrophenylhydrazine

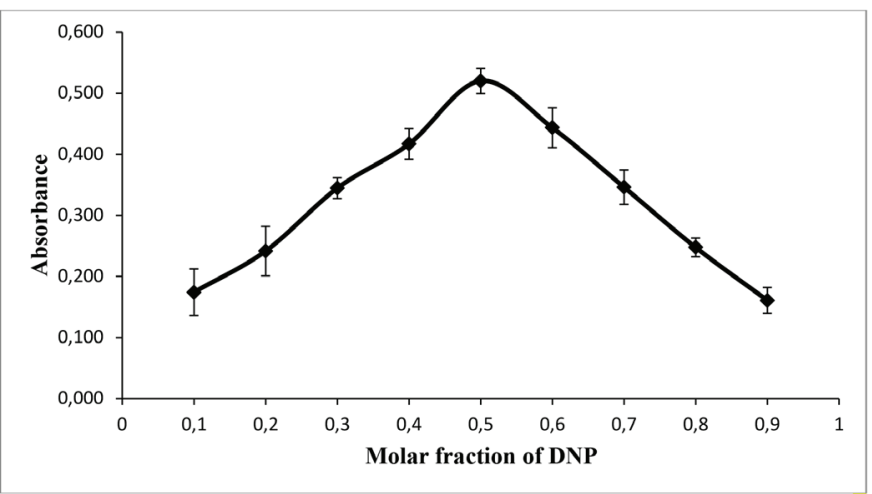

Figure 3. Determination of stoichiometric ratio by Job's method. DA and DNP are $3 \times 10^{-3} \mathrm{M}$, absorbance is average of three determinations. Error bars represent standard deviation

DA: Dopamine, DNP: 2,4-dinitrophenylhydrazine 
the absorbance at $560 \mathrm{~nm}$ and $X$ is the concentration of DA $(\mu \mathrm{g} /$ $\mathrm{mL}$ ). The linear range was $5-50 \mu \mathrm{g} / \mathrm{mL}$. The molar absorptivity (ع) was $7.9 \times 10^{4} \mathrm{~L} / \mathrm{mol} . \mathrm{cm}$. The limit of detection (LOD) and limit of quantitation (LOQ) were calculated as $3.3 \sigma / \mathrm{S}$ and $10 \sigma / \mathrm{S}$, respectively, ${ }^{36}$ where $\sigma$ is the residual standard deviation of the regression line and $S$ is the slope of the regression line. The $L O D$ and $L O Q$ were 0.32 and $0.97(\mu \mathrm{g} / \mathrm{mL})$, respectively.

\section{Accuracy, precision, and specificity}

The accuracy was evaluated by recovery studies for added standard concentrations to a pre-analyzed product at low, intermediate, and high concentrations. The recovery values were $99.5-101.9 \pm 0.21-1.12 \%$ (Table 3 ), indicating the accuracy of the method. Intraday precision was assessed at three different

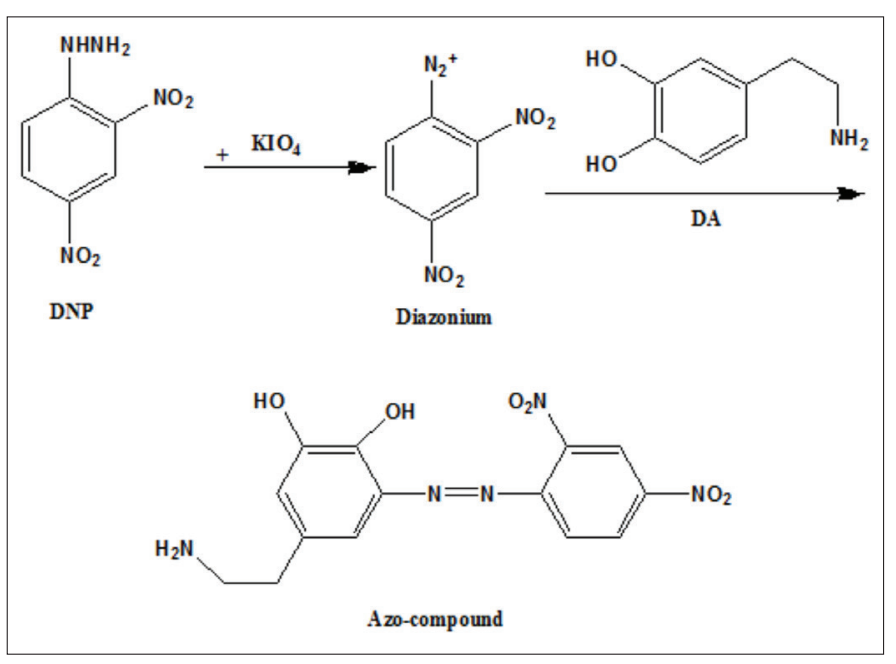

Figure 4. Suggested reaction of DA derivatization

DA: Dopamine, DNP: 2,4-dinitrophenylhydrazine

Table 3. Recovery studies for determination of DA by the developed method

Pre-analyzed product $^{\mathrm{a}}(\mu \mathrm{g} / \mathrm{mL})$

Added DA $(\mu \mathrm{g} / \mathrm{mL})^{\mathrm{b}} \quad$ Recovery $\%(\text { Mean } \pm \mathrm{SD})^{\mathrm{c}}$

\begin{tabular}{|c|c|c|}
\hline \multirow{3}{*}{10} & 5 & $101.2 \pm 0.83$ \\
\hline & 10 & $99.5 \pm 1.01$ \\
\hline & 15 & $100.8 \pm 0.98$ \\
\hline \multirow{3}{*}{15} & 7.5 & $100.4 \pm 1.12$ \\
\hline & 15 & $101.8 \pm 0.21$ \\
\hline & 22.5 & $100.4 \pm 0.57$ \\
\hline \multirow{3}{*}{20} & 10 & $101.9 \pm 0.30$ \\
\hline & 20 & $100.5 \pm 0.73$ \\
\hline & 30 & $100.2 \pm 0.81$ \\
\hline
\end{tabular}

a: DA ampoule labeled to contain $200 \mathrm{mg} / 5 \mathrm{~mL}$, found $198.6 \pm 0.1 \mathrm{mg} / 5 \mathrm{~mL}$ by the developed method, appropriate dilution was done, b: Standard DA was added to a pre-analyzed product at $50 \%, 100 \%$, and $150 \%$, c: Values are means of three determinations

DA: Dopamine, SD: Standard deviation concentrations by analyzing five replicates per concentration on the same day. Interday precision was determined by analyzing samples for 6 consecutive days within a week (Table 4). The percentage of RSD did not exceed $2 \%$, proving the high precision of the method. Before proceeding with the analysis of DA in its dosage forms, interference liabilities were determined to examine the effect of excipients that might be added during formulation. Samples were prepared by mixing 10 and $40 \mathrm{mg}$ of DA with excipients like sodium bisulfate $(0.05 \mathrm{~g})$ and dextrose (5.0 g). These laboratory-prepared samples were analyzed by the developed method. The recovery values were 98.9$100.4 \pm 0.31-1.21 \%$ (Table 5). These data confirmed the absence of interference from excipients with DA determination by the developed method.

\begin{tabular}{lll}
\multicolumn{3}{l}{ Table 4. Evaluation of intra- and interday precision } \\
\hline DA concentration $(\mu \mathrm{g} / \mathrm{mL})$ & Intraday $(\mathrm{n}=5)$ & Interday $(\mathrm{n}=6)$ \\
\hline & RSD $\%$ & RSD \% \\
\hline 5 & 0.99 & 1.5 \\
\hline 20 & 1.14 & 0.65 \\
\hline 40 & 0.64 & 0.42 \\
\hline
\end{tabular}

DA: Dopamine, RSD: Relative standard deviation

\begin{tabular}{lll} 
Table 5. Interference liabilities from excipients & $\begin{array}{l}\text { DA concentration } \\
(\mu \mathrm{g} / \mathrm{mL})\end{array}$ & $\begin{array}{l}\text { Recovery \% } \\
\text { Excipients }\end{array}$ \\
\cline { 2 - 3 } & $\begin{array}{ll}\text { Mean } \pm \text { SD) } \\
\text { Sodium bisulfite }\end{array}$ & $99.21 \pm 0.31$ \\
\hline 40 & $100.4 \pm 0.73$ \\
\hline Dextrose & 10 & $98.9 \pm 1.21$ \\
\hline 40 & $99.6 \pm 0.58$ \\
\hline
\end{tabular}

a: Values are means of three determinations, DA: Dopamine, SD: Standard deviation

\section{Robustness and ruggedness}

Robustness was evaluated by studying the influence of small variations in the method variables on its analytical performance. One parameter was changed while the others were kept unchanged and the recovery values were calculated each time. The recovery values were 98.6-101.1 $\pm 0.31-1.12$ (Table 6). This indicated the reliability of the method. Regarding ruggedness, lab-to-lab variations were examined by performing DA analysis using the same operational conditions but using two different instrumentations. The results obtained were reproducible, as RSD did not exceed $1.43 \%$ (Table 7 ).

\section{Application of the method}

DA pharmaceutical dosage forms (ampoule, infusion fluid) were analyzed successfully by the developed method. The results comply with the USP 29 specifications of DA content in injection (95-105\%). ${ }^{40}$ Comparison of the result with the reference data ${ }^{5}$ by statistical analysis with respect to accuracy 
Table 6. Robustness of the method

\begin{tabular}{|c|c|c|}
\hline Parameter & Variation & $\begin{array}{l}\text { Recovery\% } \\
(\text { Mean } \pm \text { SD) }\end{array}$ \\
\hline \multicolumn{3}{|c|}{ DNP concentration } \\
\hline & $0.004 \mathrm{M}$ & $99.6 \pm 0.41$ \\
\hline & $0.006 \mathrm{M}$ & $98.9 \pm 0.64$ \\
\hline \multicolumn{3}{|c|}{ Volume of 0.005 M DNP } \\
\hline & $0.8 \mathrm{~mL}$ & $101.1 \pm 0.93$ \\
\hline & $1.2 \mathrm{~mL}$ & $100.5 \pm 0.76$ \\
\hline \multicolumn{3}{|c|}{ PPI concentration } \\
\hline & $0.0057 \mathrm{M}$ & $98.6 \pm 1.12$ \\
\hline & $0.0074 \mathrm{M}$ & $99.3 \pm 0.31$ \\
\hline \multicolumn{3}{|c|}{ Volume of $0.0065 \mathrm{M} \mathrm{PPI}$} \\
\hline & $0.8 \mathrm{~mL}$ & $100.2 \pm 0.86$ \\
\hline & $1.2 \mathrm{~mL}$ & $99.1 \pm 0.37$ \\
\hline \multicolumn{3}{|c|}{$\mathrm{NaOH}$ concentration } \\
\hline & $9.8 \mathrm{M}$ & $98.7 \pm 0.54$ \\
\hline & $10.2 \mathrm{M}$ & $99.2 \pm 0.62$ \\
\hline \multicolumn{3}{|c|}{ Volume of $10 \mathrm{M} \mathrm{NaOH}$} \\
\hline & $0.4 \mathrm{~mL}$ & $101.5 \pm 1.5$ \\
\hline & $0.6 \mathrm{~mL}$ & $99.3 \pm 1.5$ \\
\hline \multicolumn{3}{|c|}{ Temperature } \\
\hline & $23^{\circ} \mathrm{C}$ & $99.25 \pm 0.14$ \\
\hline & $27^{\circ} \mathrm{C}$ & $100.55 \pm 0.39$ \\
\hline
\end{tabular}

a: Values are means of three determinations; the concentration of DA was $20 \mu \mathrm{g} / \mathrm{mL}$ DA: Dopamine, DNP: 2,4-dinitrophenylhydrazine, PPI: Potassium periodate, $\mathrm{NaOH}$ : Sodium hydroxide, SD: Standard deviation

Table 7. Ruggedness of the method

\begin{tabular}{lllll}
$\begin{array}{l}\text { DA concentration } \\
(\mu \mathrm{g} / \mathrm{mL})^{\mathrm{a}}\end{array}$ & \multicolumn{2}{l}{ Shimadzu UV-1601 } & \multicolumn{2}{l}{ Perkin Elmer Lambda 25 } \\
\hline & $\begin{array}{l}\text { Recovery \% } \\
(\text { Mean } \pm \text { SD) }\end{array}$ & RSD \% & $\begin{array}{l}\text { Recovery \% } \\
\text { (Mean } \pm \text { SD) }\end{array}$ & RSD \% \\
\hline 5 & $98.3 \pm 1.41$ & 1.43 & $98.6 \pm 1.22$ & 1.24 \\
\hline 20 & $100.7 \pm 0.47$ & 0.47 & $98.8 \pm 0.58$ & 0.59 \\
\hline 40 & $98.6 \pm 0.43$ & 0.44 & $99.7 \pm 0.29$ & 0.29 \\
\hline
\end{tabular}

a: Three determinations per concentration, RSD: Relative standard deviation, DA: Dopamine, UV: Ultraviolet, SD: Standard deviation

by t-test showed that there was no significant difference at the 95\% confidence level. This confirms similar accuracy in the determination of DA by the two methods (Table 8).

\section{DISCUSSION}

DA contains a catechol group, which can be coupled with a diazonium cation in basic solution to produce a red shifted azo derivative. A simple one-step procedure was achieved for spectrophotometric analysis of DA after derivatization with DNP. The reaction was completed immediately at room temperature,
Table 8. Determination of DA in dosage forms by developed method and comparison with reference data

\begin{tabular}{lll} 
Dosage forma & \multicolumn{2}{l}{ Recovery \% $(\text { Mean } \pm \text { SD })^{\mathrm{b}}$} \\
\hline & DNP method & Reference data $^{5}$ \\
\hline \multirow{3}{*}{ Ampoule } & $99.32 \pm 0.51$ & \\
& $(\mathrm{t}=1.6567, \mathrm{p}$ & $98.56 \pm 0.89$ \\
& value $=0.1362)$ & \\
\hline
\end{tabular}

DA and dextrose infusion solution

$95.81 \pm 0.87$

a: Labeled to contain $200 \mathrm{mg} / 5 \mathrm{~mL}$ DA per ampoule or $0.8 \mathrm{mg} / \mathrm{mL}$ DA and $5 \%$ dextrose infusion solution, ${ }^{b}$ : Values are means of five determinations, $p$ value $>0.05$ nonsignificant difference, DA: Dopamine, SD: Standard deviation, DNP: 2,4-dinitrophenylhydrazine

which is advantageous in comparison to other spectroscopic DA assays. Heating at 30,40 , and $75^{\circ} \mathrm{C}$ and adjustment of $\mathrm{pH}$ using a buffer were required for 4-aminoantipyrine-, ${ }^{10}$ bromanil-, 6 and 2-hydroxynaphthaldehyde-based ${ }^{11}$ spectroscopic analysis of $D A$, respectively. A derivatization reaction was described for spectroscopic analysis of DA based on the formation of intensely colored Prussian blue that required 35 min for completion. ${ }^{9}$ In addition, the developed method exhibited enhanced sensitivity $\left(\varepsilon 7.9 \times 10^{4} \mathrm{~L} / \mathrm{mol} . \mathrm{cm}\right)$. The recorded molar absorptivities $(\varepsilon$ ) for spectrophotometric DA determination were $3.475 \times 10^{3}, 6.47 \times 10^{3}$, and $7.4 \times 10^{3} .4,6 \mathrm{~A}$ HPLC assay for DA analysis showed a range $(12-40 \mu \mathrm{g} / \mathrm{mL})$ comparable with that of the developed method. ${ }^{12}$ Chromatographic methods require highly sophisticated instruments and expensive solvents.

The results of the validation studies were in good agreement with $\mathrm{ICH}$ guidelines. The method was accurate and precise. The results for interference liabilities proved the specificity of the developed method; thus it can be applied for DA analysis in its dosage forms. The statistical analysis showed that the developed method is comparable with a reference method ${ }^{5}$ for analysis of DA.

\section{CONCLUSION}

The developed method has the advantages of being simple, rapid, sensitive, accurate, and low cost, and does not require any pretreatment of the drug. The method was applied successfully for analysis of DA in dosage forms without interference from excipients. Therefore, it can be suitable for routine analysis of DA in quality control laboratories.

\section{ACKNOWLEDGMENTS}

I would like to thank Al-Shifa hospital pharmacy (Gaza, Palestine) for supplying the DA dosage forms.

Conflicts of interest: No conflict of interest was declared by the authors. The authors alone are responsible for the content and writing of the paper.

\section{REFERENCES}

1. Ford SM, Roach SS. Roach's Introductory Clinical Pharmacology (10 th ed). Philadelphia; Lippincott, Williams \& Wilkins; 2013:350-362. 
2. Boulain T, Runge I, Bercault N, Benzekri-Lefevre D, Wolf M, Fleury C. Dopamine therapy in septic shock: detrimental effect on survival? J Crit Care. 2009;24:575-582.

3. Al-Abachi MQ, Al-Da'amy MA. Spectrophotometric determination of catechol amine drugs in pharmaceutical preparations via oxidative coupling reaction with 3-amino pyridine and sodium periodate. Irq Nat J Chem. 2005;18:226-234.

4. Al-Sharook MM. Spectrophotometric determination of catecholamines in pharmaceutical preparations via charge transfer complex formation using bromanil reagent. J Edu Sci. 2007;19:1-11.

5. Idris RM, Gadkariem EA, Ibrahim KE, Mohamed MA. Development of spectrophotometric method for determination of dopamine hydrochloride in bulk and injectable forms. Res J Pharm Biol Chem Sci. 2012;3:1135-1145.

6. Nagaraja P, Murthy KC, Rangappa KS, Gowda NM. Spectrophotometric methods for the determination of certain catecholamine derivatives in pharmaceutical preparations. Talanta. 1998;46:39-44.

7. Nagaraja P, Murthy KC, Yathirajan HS, Mohan BM. Rapid spectrophotometric determination of dopamine hydrochloride with chloramine-T. Indian J Pharm Sci. 1998;60:99-101.

8. Nagaralli BS, Seetharamappa J, Melwanki MB, Ramesh KC, Keshavayya J. Spectrophotometric investigations of the assay of physiologically active catecholamines in pharmaceutical formulations. J AOAC Int. 2002;85:1288-1292.

9. Guo L, Zhang Y, Li Q. Spectrophotometric determination of dopamine hydrochloride in pharmaceutical, banana, urine and serum samples by potassium ferricyanide-Fe(III). Anal Sci. 2009;25:1451-1455.

10. Mohamed GG, Nour-El-Dien FA, El-Nahas RG. Spectrophotometric and standard addition methods for quantitative determination of dopamine hydrochloride and levodopa in tablets and ampoules. Afinidad. 2009;541:243-251.

11. Rajper AD, Arain GM, Rind FMA, Khuhawar MY. Spectrophotometric and liquid chromatographic determination of dopamine from pharmaceutical preparations using 2-hydroxynaphthaldehyde as derivatizing reagent. Asian J Chem. 2007;19:4817-4824.

12. Cosmin R, Marius B, Ancamaria N. Validation of a HPLC method of dopamine hydrochloride determination from injectable preparation. Clujul Med. 2009;82:520-523.

13. Sanchez A, Menezes M, Pereira O. Determination of catecholamines in plasma from rats by direct injection using HPLC. Salusvita. 2001;20:7987.

14. Rao PS, Rujikarn N, Luber JM, Tyras DH. A specific sensitive HPLC method for determination of plasma dopamine. Chromatographia. 1989;28:307-310.

15. Zhao H, Mun H, Bai Y, Yu H, Hu Y. A rapid method for the determination of dopamine in porcine muscle by pre-column derivatization and HPLC with fluorescence detection. J Pharm Anal. 2011;1:208-212.

16. Nevado JJB, Gallego JML, Laguna PB. Flow-injection spectrophotometric determination of adrenaline and dopamine with sodium hydroxide. J Pharm Biomed Anal. 1996;14:571-577.

17. Al-Abachi $M Q$, Sinan $R$, Haddi $H$. Spectrophotometric determination of methyldopa and dopamine hydrochloride in pharmaceutical preparations using flow injection analysis. Nat J Chem. 2009;36:597-604.

18. Subrata K, Ghosh SK, Madhuri M, Anjali P, Tarasankar P. Fluorimetric determination of dopamine via its derivatization with 1,2-phenylenediamine. J Indian Chem Soc. 2004;81:868-873.
19. Kuo IT, Huang YF, Chang HT. Silica nanoparticles for separation of biologically active amines by capillary electrophoresis with laserinduced native fluorescence detection. Electrophoresis. 2005;26:26432651.

20. Nalewajko E, Wiszowata A, Kojto A. Determination of catecholamines by flow-injection analysis and high-performance liquid chromatography with chemiluminescence detection. J Pharm Biomed Anal. 2007;43:16731681.

21. Yu Z, Li X, Wang X, Ma X, Li X, Cao K. Voltammetric determination of dopamine and norepinphrine on a glassy carbon electrode modified with poly (L-aspartic acid). J Chem Sci. 2012;124:537-544.

22. Ören T, Birel Ö, Anık Ü. Electrochemical determination of dopamine using a novel perylenediimide-derivative modified carbon paste electrode. Anal Lett. 2018;51:1680-1693.

23. Lai GS, Zhang HL, Han DY. Electrocatalytic oxidation and voltammetric determination of dopamine at a nafion/carbon-coated iron nanoparticleschitosan composite film modified electrode. Mikrochim Acta. 2008;160:223-233.

24. Stoytcheva M, Zlatev R, Velkova Z, Gochev V, Montero G, Toscano L, Olivas A. Advances in the electrochemical analysis of dopamine. Curr Anal Chem. 2017;13:89-103.

25. Redžić S, Kahrović E, Zahirović A, Turkušić E. Electrochemical determination of dopamine with ruthenium (III) modified glassy carbon and screen printed electrodes. Anal Lett. 2016;50:1602-1619.

26. Vinoth V, Wu JJ, Anandan S. Sensitive electrochemical determination of dopamine and uric acid using AuNPs $_{(\mathrm{EDAS})}-\mathrm{rGO}$ nanocomposites. Anal. Methods. 2016; 22:4379-4390.

27. Shravya A, Chandan RS, Gurupadayya BM, Sireesha M. Spectrophotometric determination of atorvastatin and ezetimibe using 2,4-DNP in bulk and pharmaceutical dosage forms. Int J Pharm Technol. 2010;2:1046-1056.

28. Nagaraja P, Shrestha AK. Spectrophotometric method for the determination of drugs containing phenol group by using 2,4-dinitrophenylhydrazine. J Chem. 2010;7:395-402.

29. Sowjanya K, Thejaswini JC, Gurupadayya BM, Priya MI. Spectrophotometric determination of pregabalin using 1,2-napthaquinone-4-sulfonic acid sodium and 2,4-dinitrophenylhydrazine in pharmaceutical dosage form. Pharm Lett. 2011;3:47-56.

30. Sai Praveen P, Anupama B, Jagathi V, Devala Rao G. Spectrophotometric determination of Tolperisone using 2,4-dinitrophenylhydrazine reagent. Int J Res Pharm Sci. 2010;1:317-320.

31. Abdelmageed $\mathrm{OH}$. Development and validation of a spectrophotometric method for the determination of macrolide antibiotics by using 2,4-dinitrophenylhydrazine. J AOAC Int. 2007;90:364-371.

32. Watson GD. Pharmaceutical Analysis: A Textbook for Pharmacy Students and Pharmaceutical Chemists ( $2^{\text {nd }}$ ed). London; Churchill Livingstone; 2005:97-116.

33. Ramadan M. O-Phthalaldehyde based spectrophotometric method for determination of sitagliptin in tablets. Int J Pharm Pharm Sci. 2014;6:125129.

34. Ramadan M, Abuiriban A. NQS assisted spectrophotometric determination for aliskiren in pharmaceutical dosage form. Am J Anal Chem. 2013;3:105 113

35. Job P. Advanced Physicochemical Experiments ( $2^{\text {nd }}$ ed). Edinburgh; Oliver and Boyd; 1964:45. 
36. ICH Harmonized tripartite guideline, Validation of analytical procedures: Text and Methodology Q2(R1). In Proceedings of the International Conference on Harmonization, Geneva; 2005.

37. Morrison RT, Boyd RN. Organic Chemistry ( $6^{\text {th }}$ ed). New Jersey; Prentice Hall; 1992:864-866.

38. March J. Advanced Organic Chemistry: Reactions, Mechanisms and Structure. (4th ed). New York; John Wiley \& Sons; 1992:635-637.
39. Herbst W, Hunger K. Industrial Organic Pigments: Production, Properties, Applications ( $3^{\text {rd }}$ ed). Weinheim; Wiley-VCH; 2004:197-205.

40. United States Pharmacopeia 24 -National Formulary 19. Rockville; United States Pharmacopeial Convention Inc.; 2007:754-755. 